http://dx.doi.org/10.11646/phytotaxa.142.1.6

\title{
A new infraspecific taxon of Phyllanthus myrsinites (Phyllanthaceae) from the Brazilian Amazon
}

\author{
RICARDO DE S. SECCO ${ }^{1}$
}

${ }^{I}$ Museu Paraense Emilio Goeldi, Av. Magalhães Barata, 376, CEP 66040-170, Belém, Pará, Brazil; E-mail: rsecco@museu-goeldi.br

\begin{abstract}
Phyllanthus myrsinites subsp. platyphyllus, a new subspecies from Amazonas States, Brazil, is described and illustrated. It differs from Phyllanthus myrsinites subsp. myrsinites in its wide-orbiculate leaves that can be up to $2.7 \mathrm{~cm}$ wide, with a subapical gland 4-5 mm from the apex, secondary veins evident on the adaxial surface, and staminate flowers grouped only in the leaf axils.
\end{abstract}

Key words: Brazilian Flora, new subspecies, plant taxonomy

\section{Resumo}

Phyllanthus myrsinites subsp. platyphyllus, uma nova subespécie do Estado do Amazonas, Brasil, é descrita e ilustrada. Difere de Phyllanthus myrsinites subsp. myrsinites pelas folhas largo-orbiculadas, que podem atingir até $2,7 \mathrm{~cm}$ de largura, com uma glândula subapical localizada abaixo de $4-5 \mathrm{~cm}$ do ápice, nervuras secundárias evidentes na face adaxial e flores estaminadas agrupadas apenas nas axilas das folhas.

\section{Introduction}

Phyllanthus Linnaeus (1753: 981) is the largest genus of Phyllanthaceae comprising about 800 species (Radcliffe-Smith 2001) with a pantropical distribution, of which ca. 200 species occur in the Americas. Approximately 90 species are distributed throughout Brazil, according to surveys published in the Species List of the Brazilian Flora (Secco et al. 2013). These species have varying habits, but are generally herbaceous, with cymose inflorescences, sometimes reduced to a single flower, monochlamydeous, gamosepalous, rarely polysepalous flowers, entire or segmented disk, free or joined stamens, anthers dehiscing horizontally, obliquely to vertically, styles 3 , free or united, fruit a septicidal capsule, rarely bacaceous or drupaceous, and seeds trigonous.

Phyllanthus myrsinites Kunth (1817: 11) is one of the most variable species of the genus in terms of leaf morphology which has resulted in the proposal of many superfluous species based on individual specimens and made its taxonomy quite confusing, such as $P$. dinizii Huber (1914: 182), P. gallinetae Jablonski (1967: 111), P. glaucoviridis Jablonski (1967: 101), which are all considered synonyms of $P$. myrsinites, as well as $P$. pimichianus Jablonski (1967: 111), which is a synonym of $P$. myrsinites subsp. francavillanus (Müller 1863: 20) Webster (1999: 198).

During a revision of the species of Phyllanthus from the Brazilian Amazon and additional studies directed towards updating Phyllanthaceae for the Species List of the Brazilian Flora (Secco et al. 2013), specimens that had been identified as a probable new subspecies by the late Dr. Grady L. Webster were encountered. After a detailed investigation, especially of the published works of Jablonski (1967) and Webster (1956, 2002a, 2002b, 2003, 2004) it was determined that many of the studied specimens did in fact represent a new infraspecific taxon. The new subspecies is described, commented, and illustrated here. 
Webster (1999) proposed P. myrsinites subsp. francavillanus based on the shape of the branches (more or less flattened), leaves obovate to oblong, and the size (ca. $0.5 \mathrm{~mm}$ diameter) and position of the subapical gland (mostly $<1 \mathrm{~mm}$ from the apex). However, in analyzing the vast collections of $P$. myrsinites subsp. myrsinites deposited in the IAN, INPA, MG, and NY herbaria, it was noticed that the characteristics used by Webster (1999) to propose P. myrsinites subsp. francavillanus were also present in every individual of $P$. myrsinites subsp. myrsinites. Consequently, these characteristics could not be used to distinguish different subspecies, and the synonymization of $P$. myrsinites subsp. francavillanus with P. myrsinites subsp. myrsinites is proposed here.

\section{Acknowledgments}

The author would like to thank CNPq for the PQ grant (process n. 303424/2010-9) awarded for the study of the Amazonian Euphorbiaceae/Phyllanthaceae; the curators of the IAN, INPA, MG, and NY herbaria for their permission to examine their collections; Carlos Alvarez for preparing the species illustrations; Dr. William Rodrigues of the Universidade Federal do Paraná for the Latin diagnosis, and Roy Funch for English version.

\section{References}

Huber, J. (1914) Plantae Duckeanae Austro-Guyanenses. Euphorbiaceae. Bulletin de la Société Botanique de Genève, Sér. 2. 6: 179-212.

Jablonski, E. (1967) Euphorbiaceae. In: Maguire, B. (ed.), Botany of the Guayana Highland-Part VII. Memoirs of the New York Botanical Garden 17: 80-190.

Kunth, K.S. (1817) Euphorbiaceae. Nova Genera et Species Plantarum (quarto ed.) 2: 406 pp.

Linnaeus, C. (1753) Species Plantarum. Imprensis Laurentii Salvii, Holmiae. 1200 pp.

Müller, J. (1863) Euphorbiaceae. Vorläufige Mitteheilungen aus dem für De Candolle's Prodromus bestimmten Manuscript über diese Familie. Linnaea 32: 1-126.

Radcliffe-Smith, A. (2001) Genera Euphorbiacearum. Royal Botanic Gardens, Kew, 445 p., il.

Secco, R., Cordeiro, I. \& Martins, E.R. (2013) Phyllanthaceae. In: Campostrini Forzza, R., Stehmann, J. R. \& Nadruz, M. (eds.), Lista de Espécies da Flora do Brasil. Jardim Botânico do Rio de Janeiro. (http://floradobrasil.jbrj.gov.br/ jabot/floradobrasil/FB24160). Accessed 09 April 2013.

Thiers, B. (2013) Index Herbarium. A global directory of hebaria and associated staff. New York Botanical Garden's Virtual Herbarium. (http://sweetgum.nybg.org/ih/). Accessed 02 July 2013.

Webster, G.L (1956) A monographic study of the West Indies species of Phyllanthus. Journal of the Arnold Arboretum 37: 91-122, 217-268, 340-359.

Webster, G.L. (1999) Phyllanthus. In: Steyermark, J.A., Berry, P.E., Yatskievich, K. \& Holst, B.K. (eds.), Flora of Venezuelan Guayana, vol. 5: 191-205. St. Louis, Missouri Botanical Garden Press.

Webster, G.L. (2002a) Three new sections and a new subgenus of Phyllanthus (Euphorbiaceae). Novon 5: $290-298$. http://dx.doi.org/10.2307/3392970

Webster, G.L. (2002b) A synopsis of the Brazilian taxa of Phyllanthus section Phyllanthus (Euphorbiaceae). Lundellia 5: $1-26$.

http://dx.doi.org/10.2307/4117335

Webster, G.L. (2003) A synopsis of Phyllanthus section Nothoclema (Euphorbiaceae). Lundellia 6: 19-36.

Webster, G.L. (2004) A revision of Phyllanthus section Hylaeanthus (Euphorbiaceae). Lundellia 7: 11-27. 